\title{
Changing Over From Criticism To Protectionism In Media Literacy Classes. Source Texts In Turkey
}

\author{
A. Asli Sezgin, PhD \\ Osmaniye Korkut Ata University, Osmaniye, Turkey
}

doi: 10.19044/esj.2016.v12n11p35 URL:http://dx.doi.org/10.19044/esj.2016.v12n11p35

\begin{abstract}
Approachments, basically, are related to the subject of media literacy. The different practices sourced from these approachments have been remarked since the inception of media literacy subject discussions until today. The diversifying of media tools is dependent on its technological development. Thus, it is reaching broader areas which are necessary for evaluating the media literacy in a different and wider view. When the attempts of the government structures about the subject in Turkey and the courses were examined, wordings which have become different, over the years, in source texts have been given so much attention. Media literacy class source texts have been prepared in a critical language in Turkey. However, it is been passed into a protective and interferant wording in terms of time more than criticism. In this study, firstly, the differences between protective and interferant approachments will be explained with a critical approach directed towards media literacy. Right after that, the content of two (2) different sourced texts which has been prepared for study in the media literacy classes in Turkey will be examined based on the period they were published.
\end{abstract}

Keywords: Media Education, Media Literacy, Critical Media Literacy, Protectionist Approach

\section{Introduction}

The concept of media literacy adopted by the attempts that has began in America at the end of the 1920s and in the early 1930s, is being evaluated as a concept that must be taken elaborately. However, its value is increasing day by day. Media literacy concept plays an important role in interpreting the media messages that was affected without being aware or not.

Media literacy can be defined as the ability of reaching, analyzing, evaluating, and transmitting messages in various forms (Hobbs, 1998). Media literacy helps us to gather ways in the sea of images and voices. 
Today, we do not receive information about the events happening in the world from only words written on a piece of paper. Thus, efficient images and voices were obtained by different media (Thoman \& Jolls, 2008). Subsequently, the concept of "literacy" can be defined as the ability of reading that is associated with the printed media in the minds of many people. Thus, some people have enlarged this concept to visual literacy with the use of television and cinema. Furthermore, reading or visual literacy does not have a synonym with the media literacy. Media literacy is a concept that includes all of these attributes, features, and many more (Potter, 2004). Media has a visual-audial language that has its own rules, and is used for the purpose of transmitting different incidents, concepts, and opinions. Consequently, media literacy is the ability of accurately evaluating, analyzing, and reconstructing the media in various forms. In addition, media literacy is a 21st century approachment to education (Thoman \& Jolls, 2008).

Today, media education that aims to educate new generations in the direction of perceiving different information in the modern information society, even provides the ability of benefitting from the mass media in the maximum level. Its aim is to provide cultural development by mass media, critical thinking, perceiving, interpreting, creativity, and the evaluating of media texts with media education. At the end of the process, the individual who is now a media literate will have the ability of using media content in various forms, as well as in benefiting from them (Fedorov, 2003). At this point, it is important to underline the difference between media education and media literacy. Federov (2003) has requested from 26 media educators from 10 different countries including even Russia, Spain, USA, and Belgium, to evaluate 3 different media education and media literacy concepts that has been made by expert people in the field. These experts who joined the research have agreed with the study of Aufderheide (1993) with a ratio of 61,54\%. Thus, Aufderheide (1993) defined the media literacy as "practice that reads and produces media which constitutes the voices, sounds, and words; and it creates the view of information." In addition, they also made different offers and definitions with that description.

According to Aufderheide (1993), a media literate can read, solve, analyse, and produce printed or electronic media at the same time. The main purpose of the media literacy is to train individuals to be well-informed about the content of media. However, these individuals have the ability of aesthetic discrimination and explanation; have the responsibility in the social contex; and have the understanding of conscious consumption. Strategies and processes that have different emphasizes were encountered in the activity of media literacy. While some opinions evaluate the media literacy as a tool that is used for understanding the substructure of mass media, media literacy is evaluated as a method that is used for examining the aesthetic features 
which are represented by the media using a different approach (Aufderheide, 1993).

Livingstone (2004) explains media literacy with a definition that has four compounds. Therefore, media literacy must have the abilities of reaching, analyzing, evaluating media content, and designing new messages. Therefore, these four compounded definition is important in terms of printed media, visual-audial media, and the involvement of internet content (Livingstone, 2004). Livingstone (2004) has defined these four compounds in the definition of media literacy, under the different titles as:

-Access: Access to the media content is an important process in terms of evaluating the quality and persistence of presenting the service (Livingstone, 2004).

-Analysis: Readers and audiences of the media content must be motivated and competent about these content and related cultural values (Livingstone, 2004). Hence, this is possible with the ability of accurate analyzing of the subjected media content.

-Evaluation: When we think of an individual who is drowned on the pile of information through the internet environment, it is possible to say that he will encounter difficulties in choosing the beneficial one from the various contents. This basically occurs when he does not have evaluation ability. Evaluating media content must not be considered as a simple process. While evaluating the media content with a critical approach, information related to its social, cultural, economical, political, and historical context are also required for consideration (Livingstone, 2004).

-Content Creation: Within the last years, everyone has become a media producer, especially with the usage of internet technologies. Today, the subject of producing content in the media literacy prgramme needs to be more research. Thus, this is in terms of examining the relationship between receiving and producing the media content in the new media environment (Livingstone, 2004).

After examining the explanations about the media literacy definitions and compounds of these definitions, some of the factors that increase the affect of media literacy programme are required for indication. The media literacy programme which is structured with the ability of sustainability and which is prepared with a valid and applicable research substructure, can be applied at different times. In addition, the material that makes the structural development to be sustainable can be applied more efficiently and meaningfully (Brown, 1998).

It is possible to collect the researches about the application of the programme and the curricula of the media literacy programme. Thus, this was beside the studies about the concept of media literacy, under the title of teaching techniques and evaluation of these techniques. The purpose of the 
media literacy class content must be to educate the students as informed media literates. A curriculum directed to understanding the structure of media messages must be adopted. Thus, skeptic approach that can be developed against these messages must be prevented. The structure which is open to the dialogue of media literacy education will help in the democratization of teacher-student relationship. In the evaluation process, the answer to the question of whether a student should become a media literate or not, must be sought. While doing that, we are faced with the question of "will we evaluate the information, attitude and behaviors, values, and the effects of media on all of these?” Furthermore, an efficient media literate must be able to produce media content in an informed way while he already has the ability of using it in various forms of media content (Christ \& Potter, 1998).

In the prospective vision of media literacy class, it is possible to say that it will reach its aim if it is carried out meticulously with a teaching staff that has intellectual accumulation. This teaching staff can increase the teaching quality and can contribute to evaluating shared experiences, teaching strategies and approaches at the same time (Hobbs, 1998).

New media content added to the media content has been focused on the explanations which have been made on the subject of the media education and media literacy in the last years. Consequently, this media content has increased the importance given to the studies of media literacy in this era regarded as digital era. In this new digital era which has continuous information flow, literacy in traditional meaning has fallen short. Instead of that, people of all ages need to improve themselves on media literacy against this information flow. The concept of digital literacy which has to be discussed took place after this awareness. Digital literacy is now being evaluated as a life style in participation to new social order which is known as information society. Digital literacy presents a wider participation field to media literacy. In addition, digital literacy incites us to learn lifelong at the same time (Buckingham, 2009).

As the report evaluates current approaches related to media literacy that has been published by European Commission, milestones which are related to literacy have been clarified according to the historical development process. Therefore, visual-audial literacy period which have been faced with different education approaches has followed the classical literacy period. Right after that, literacy which has been applied and directed to modern digital tools with the advent of computers was employed. Finally, new media literacy concept was told, and they include digital literacy together with traditional literacy (European Commission, 2007).

Critical media literacy is told at the point of analyzing multi meanings, stereotyped messages, dominant values, and ideologies in the 
media texts that have been mentioned in the process of media literacy. In the critical media literacy, besides evaluating the media culture and media representation which are the products of social production, it is possible to develop different approaches on the subject on how to use media. Critical media literacy which teaches on how to resist the possible media manipulation shows the way of consciously benefiting from media materials at the same time (Kellner \& Share, 2005).

Kellner \& Share (2007) whose attention was drawn to the importance of critical literacy approachment in the 21st century, points that the new communication technologies is reshaping the world. Critical media literacy that has been evaluated as an approachment that spreads the literacy concept, including the affect of popular culture and new technologies, involves analyzing the relationships between media-audience-informationgovernment (Kellner \& Share, 2007).

The concept of critical media literacy which has a spreading researching literature in the years of 1980s and 1990s is defined in many different shapes. While defining the critical media literacy from the perspective of cultural studies, it is pointed that media messages is being structured by ideologies. In the postmodern approachment, critical media literacy interests how individuals position the different cultural texts according to various social and historical contexts (Alvermann \& Hagood, 2010).

\section{Media Literacy in Turkey}

After discussions and definitions directed to literacy, media education, media literacy, and critical media literacy concepts, the short development of media literacy and approachments directed towards media education in Turkey was discussed in this part of this article. Hence, this is suitable for its content.

In Turkey from 1990s, the view of the publishing industry has begun to change. This is together with the start of multiplism in the area of the television. After the national multiplism, the number of the local publishing establishments increased. Thus, publishing establishments that are indigenous to different regions of Turkey have started carrying out their activities. Different discussions have taken place based on the consequence of these developments in the media industry. The publishment contents of the television channels, value, and the qualification of the messages that are transmitted to the society constitutes the basis of these discussions (Nacaroğlu, 2006).

Almost at the same period in the dates that discussions made related to media literacy in the world (Aspen Institute - Communications and Society Program: Aspen Report of National Leadership Conference on 
Media Literacy, December 1992), the attempts in the subject of media diversity started newly in Turkey. Based on multivocality in the media, the discussions which are subjected to the transmission of media messages that have different content of the society have taken place in the consequence of these attempts.

Media studies and important historical documents in the field of media education which are taking place at Elizabeth Thoman Media Literacy Archive, and are exhibited at the symposium at Harrington School of Communication and Media at the University of Rhode Island in September 2013 with the title of Historical Roots of Media Literacy, can be evaluated as a different source that shows the media literacy studies date back many years ago (Bordac, 2014).

Media education and media literacy concept was put into consideration after the private radio and televisions were aired in the 1990s in Turkey. For the first time, they proposed an agenda in the Communication Council which occurred in 2003. Also, they expressed it as an opinion based on the subject of taking it to the curriculum at the final report (Avşar, 2014). Partaking statements in this declaration include proofs that show that the first studies to be executed in Turkey is close to critical media literacy. The expression of "protecting children from harmful broadcasts, by adopting an approachment which is not harmful to mental health" can be shown as an example.

Another conspicuous study related to the subject is the meeting that has been performed in the Turkish Grand National Assembly in July 2004. This study was done under the title of Protecting Children Against the Violence on the Media. After the meeting, Media and Violence Study Group which is constituted of the platform has published a conclusion report. However, there is a set of suggestions directed to regulations in the media related to the violence. The necessity of starting studies with the cooperation of Radio and Television Supreme Council and Ministry of National Education has even been declared in the report (The Report of Prevention of Violence Platform Media and Violence Study Group, 2004). RTSC and Ministry of National Education which began negotiations after this report has started the project of media literacy education in the year of 2004 with the protocol signed. Firstly, with the cooperation of RTSC and Ministry of National Education, 30 social sciences teachers have been trained to constitute the media literacy education in the 5 development cities chosen. Media literacy education which began in the 2006-2007 school year in 5 cities has started educating 35.000 elementary schools in 81 cities as an elective course in the classes of 6, 7, and 8 (Binar kand Gencel Bek, 2007). Elementary Schools Media Literacy Class Education Programme and Guide which has been prepared by RTCS and Ministry of National Education in the 
year of 2006 has been prepared to be taught in the media literacy class during this period.

In September 2014, a set of changes have been made in the content of media literacy class in Turkey. However, these changes have been publicized at the Meeting and Panel of Media Literacy Class Publicity. From this date, again as a publishment of RTSC and Ministry of National Education, Elementary and Imam Hatip Elementary School Media Literacy Education Material was been educated from 2014-2015 school year. Hence, this was done as the source text of the media literacy class.

In this study, after comparative examination of the two documents that were educated in the classes of media literacy in Turkey, some information will be shared about media education and media literacy approachment as a protective and interferant approachment rather than being critical.

The tracks of the interferant approachment (Semali, 2003) that focuses on negative subjects such as violence, gender, and manipulation will scan on the source texts. Therefore, this is beside the protective approachment which adopts protection of the children against negative effects of the media by censor or other similar regulations.

Media education is interpreted as a teaching strategy which must be learnt in order not to be affected by the harmful content of the media in the protective and interferant approachments (Semali, 2003). Protective approachment against media is evaluated as an approachment against the negative effects of the media in a cultural, ethical, and ideological meaning in countries which have a long historical development in the subject of media education (Buckingham, 1998). Protective approachment directed towards media education which began to dominate after the 2nd World War in France was reflected on the media education in Germany based on the church and media pedagogy (Fedorov, 2008).

A protective approachment directed towards media education is evaluated as a weak education strategy. In media education, instead of a protective approachment that focuses on the negative effects of the media, an approachment that allows helping the development of the critical abilities of the children and the possibilities for them to realize the differences between objectivity and partiality must be focused on (Bazalgette, 2008).

When we look at the regulations in the subject of media literacy in Turkey and the media literacy definition made by RTSC together with the Ministry of National Education, it is possible to see the tracks of firstly critical approachments, and then the protective approachments. Users are being warned to be more careful on the harmful effect of the media. Thus, it was defined that: "An education programme that educates the media establishments to be more careful with raising the awareness of the 
individuals, makes individuals more resistant to the negative effects of the media by giving information about the media texts” (RTSC, 2007).

Based on the studies performed in media literacy from the year 2006, the critical approachment subject is against the media. This is especially for children as they are the most open group to the effects of the media. In the same studies, the main purpose is pointed in minimising the "negative" effects of the media (Binark \& Gencel Bek, 2007).

In the protective approachment that evaluates the media education as a protective factor against the manipulation and the addiction of media, the individuals that has been influenced by the effect of a forcing culture of the media is considered as passive victims (Kellner \& Share, 2007). Consequently, when we look at the publishments that are prepared by RTSC in Turkey, emphasis about the passive receiving of children considered as "the most vulnerable target group" of media was given more attention. Violence and Suicide, Media and Police, Media and Earthquake, Susceptibility of Violence in Media, and Violence and Suicide are shown as examples to these broadcasts (RTSC, 2016).

In conclusion, some results support the critical and protective approachments which have even occurred. In a study that evaluates the opinions of the students who have taken the media literacy class, directors of schools, teachers and families, and ethical codes scale has been used as the joiners of this research. Based on the result of this research, it has been analyzed that the school directors, teachers, and families have serious worries about the quality and the content of the publishments of the channels that was broadcasted in the national diameter. Consequently, joiners have declared that the media was publishing the broadcasts which infringe on values and personal rights during the cause of rating (Elma et al., 2010).

Furthermore, this approachment is observed even in Turkey where there is a critical and protective approachment against the media broadcasts in the Elementary Media Literacy Class Curriculum and Guide. Thus, this curriculum has been prepared to be a class source in the media literacy classes which was read for the first time in 2007-2008 school year and in the Elementary and Imam Hatip Elementary School Media Literacy Teaching Material in 2014. In addition, it was prepared with the slogan -"Media Literacy Book Start Over”.

\section{Methodology}

In this study, two different source texts which are prepared to be read in the scope of media education in Turkey will be examined by content analysis method. This is done on the frame of critical media literacy and protective approachment. Elementary Media Literacy Class Curriculum and Guide that has been prepared by RTSC, Ministry of National Education in 
the year of 2006, Secondary School, and Imam Hatip Secondary School Media Literacy Teaching Material that has been prepared by, again, the same establishments and presented as lesson source in the year of 2014 are samples used in this study.

Content analysis method which is used for social researches is used in this study. Thus, content analysis which has gained importance with the spread of mass media in the society is used as a result of the use of the radio. This was used for the purpose of making propaganda in the 2nd World War. Content analysis method which is defined in various definitions in historical process can be defined as "a research technique that objectively defines the systematical definitions of declared content of the communication.” This was defined by Bernard Berelson (1952) who has contributed immensely to the usage of this method scientifically (Aziz, 1990).

Therefore, two types of content analysis involves: firstly, analyzing the scope; and secondly, analyzing the meaning of the message. Besides, in data acquisition, unitizing, sampling, limitation, analysis, and deducing steps were followed (Aziz, 1990).

The content of communication entails compromises of the inferences that have been made about the relationship of the joiners who joined this communication. The social factors, institutive and cultural dynamics that might have affected this content are needed to be taken into consideration beyond the personal assessments in the content analysis and in the content of a social incident that have been made (Gerbner, 1958). Content analysis provides an empirical base on watching the differences that might occur as a result of public opinion. Nevertheless, the quantitative side of the content analysis (word counting and frequency measurement) has caused some discussions and studies directed towards the development of the content analysis. Hence, this has also been done with the opinion that research would be limited by the quantitative side (Stemler, 2001).

Content analysis method that is used by different disciplines has helped the social sciences in subjects such as analyzing the changes of the content of the mass media, analyzing the news texts which are about the social subjects and problems, and interpreting social movements and cultural symbols (Prasad, 2008).

Furthermore, content analysis method has benefited as a qualitative research method in this study. This is because the reason for media literacy books had been examined in Turkey. In this study where written and oral materials are analyzed codedly, firstly, the main categories and coding units are designated as analysis units. However, these were defined by examples. The passing frequency of the sentences chosen as context unit in the subcategories has been located. Hence, these were explained in Table 1 (Doğan and Kılınç, 2014). 
For safety in content analyzing, coders who works independently from each other and follow the open instructions must have reached the content that provides this safety. These data must represent even the safety of the research. Thus, analyzing units must be compatible with the result of the coding of different coders (Krippendorf, 2004). Therefore, a minimum of $70 \%$ agreement must be provided between coders (Yıldırım \& Şimşek, 2006). Two different independent coders have agreement, directed towards the media literacy lesson books which are research materials to provide the safety in this research too.

"Protective approachment" and "Critical Approachment" categories are designated for the research material that will be analyzed in the study. The sub-categories under these main categories are designated as "impactviolence, trust-confidential, protect-control, hate, ideology, consumption, trap, being exposed, lies, and danger-dangerous”. In addition to the designated two (2) main categories, 11 sub-categories have been scanned by the content analysis method in the scope of both two lesson materials. Thus, the results have been shown in the table of the conclusion of the research.

11 sub-categories were explained properly based on the content of this study. Therefore, they are related to media as:

-Impact (1): When researches that are examined are made in the subject of the impact of the media, it is been talked about that the wide systematical changes of institutions and organizations is seen. This is beside the change of attitude, belief, cognition, and behaviors directed to personal contagion. In the media impact researches that evaluate the nature of the interaction between audience and media, the way media is used is majorly considered. The dynamics might be the reason for impact, source of the interaction, and provocation factors which are researched (Napoli, 2014). The impact of the media must be researched by taking into consideration the reality of the people who have different characteristics, in different social environments, under different conditions, and which have the possibility to be differently affected by the media (McQuail, 1977).

-Risk-Violence (2): One of the most discussed subjects about the media is the subject of violence. This subject which is criticized by a large segment of the society is evaluated as one of the most negative impacts of the media (Hill, 2001). When we examine the definition of the risk in the media, physical and ethical risk subject which has violence on its source is taking place. The violence factors that take place in the content directed, especially to children and teens, are used as examples of the definition of risk in the media.

-Trust (3): It is possible to say that high levels of trust provide democratization, economical stabilization, good performance, and productivity in the societies. Trust can be defined as an ethical value that is 
learned in the family in the early ages, and it requires mutual cooperation (Hakansson \& Witmer, 2015). The subject of trust on media is evaluated as a subject that is being discussed especially in the last years directed towards the developments of new media and social media usage. Digital environments that replaced face to face communication have caused some complications about the trust that provides the stabilization in the relationships. The concept of trust is uttered frequently with the concepts of risk-violence. Also, it has an impact in the protective approachment directed towards media education.

-Protection-Control (4): The researches made in the media content based on the subject of protection and control, especially in the scope of the concepts of new media and social media, is faced with the researches about protecting children and teens and controlling media content. It is possible to say that there are different opinions that belong to families, teachers, academicians, social scientist, and media experts directed to negative impacts. This is especially on children that were created by new media format depending on the technological developments. Consequently, many families have began thinking that they are losing control over protecting their children against violence, pornography, and broadcasts about consumption in the media content (Thierer, 2009). Information, especially about the potential harmful content on the new media, was given in the report (Hargrave, 2009). Therefore, this has been prepared by the experts of European Human Rights directed towards protecting the children against harmful content on the media. It is needed to take precautions directed to control and observe the children. This is with the aim of protecting them against the new media that can easily be reached without any time and space border.

-Hate (5): New media researches that have an increasing impact have been added to the researches that have been made on the hate speech. Video games, music clips, and shares that are made on social networks have caused the increase and the wide spread of hate speech in the media (Media Awareness Network, 2012).

-Ideology (6): The people who make researches about media alleged that media texts have changed the opinion of the individuals compatibly. These texts which shape our World perception style are being sourced for. This is for the purpose of showing suitable attitudes and behavior. For example, while the suitable roles of the men and women, parents, children, bosses or workers are figured by media, “success” is again defined by these texts. This feature of the media texts and the messages that is underlined and specially transformed in these texts are the basic problems. However, the questions on the ideological analysis of the media generally focus on its content more than the impact of the message (diegetic in the past and the present) (Croteau \& Hoynes, 2014). The impact that media texts have in the 
ideological meaning, especially in the beginning of the political socialization process, is important from the point of the children and teens which have the potential of being affected.

-Consumption (7): In a research directed to the shaping of consumption habits of the children by media (Tufte, 2003), the extent children are being affected as consumers in their socializing process is tried to be identified. In the research, behavior of the children about making savings and spending, content of their interests and activities, and the position of the media subjected to the recognition of trademarks are examined. In conclusion, the result of the study shows that; television being in the first place media has a central position in the daily lives of the families; recognition of trademarks consists of the early ages; gender is an important factor on purchased products; new media brings important innovations about advertisements; and children under 7 years old can realize the difference between advertisements and programmes (Tufte, 2003).

-Trap (8): "Media content” and "Trap" concepts are often explained together especially in the last years in the shares of new media and social network. Sociologist Zygmunt Bauman says that most people use social media to reach new horizons, but in reality, they incarcerate themselves into different areas. According to Bauman, there are important differences between a real social community and a virtual network. Bauman, who indicates that virtual networks are more personal, stated that instead of a real social community in virtual networks, people are experiencing their greatest horror which is loneliness. Furthermore, there is no dialogue in the social media that individual holds the control. In this environment, it is only sounds that we can hear. These sounds are the reflection of our own sound and our own reactions. In reality, this environment which gives joy is a trap directed to make people lonely (Querol, 2016).

-Exposure (9): Today, children and young people are usually exposed to media content more than six hours in their daily life. This period can be longer with televisions, computers in their rooms, music players, and mobile phones in their bags. Subsequently, economical situation and demographical features can also be effective on being exposed to media content (Roberts \& Foehr, 2008).

Being exposed to different types of the media is also affecting the development of the intelligence of the children. Television programmes that affect the mind process, and the fictional narratives on the media content, were evaluated as important factors in this development (Mar et al., 2009).

-Lie (10): In the researches related to the delusive content of the media, it was concentrated on the content in the new media which depends on the development of the internet. However, it is not possible to say that most of the young people are careful internet users. There are problems to 
have the right information that has been searched or to trust the information reached in the internet content. Young people who choose one from the various information stacks can be able to use delusive information. This situation causes children to be vulnerable against lie, fraud, and ignorance (Bartlett \& Miller, 2011).

-Danger (11): In the subject of danger on the media, the possibility of vulnerability of the children and young people in the internet content is being talked more. This danger might appear as video games with the violent contents and other content which includes pornography, addiction to internet, or cyber bullying (Whitaker \& Bushman, 2009).

\section{Results}

12 subcategories determined under the main categories of "protective approachment" and "critical approachment" has been scanned with the content analysis method in the two different books that have been prepared to be read in the media literacy class and published in 2006 and 2014. Sub categories are shown in the Table 1 with the numbers between 1-12. Therefore, this considers how frequently they pass in the chosen sentences as context unit. Besides, some sample sentences related to the conclusion of the study have been given place in the part of this scope of the result of the research.

\begin{tabular}{|c|c|c|c|c|c|c|c|c|c|c|c|}
\hline \multirow{2}{*}{ 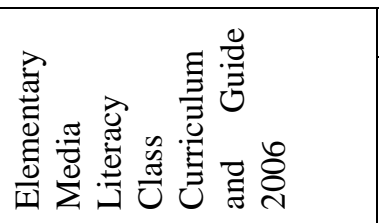 } & 1 & 2 & 3 & 4 & 5 & 6 & 7 & 8 & 9 & 10 & 11 \\
\hline & 103 & 13 & 3 & 5 & 0 & 0 & 15 & 0 & 1 & 0 & 1 \\
\hline 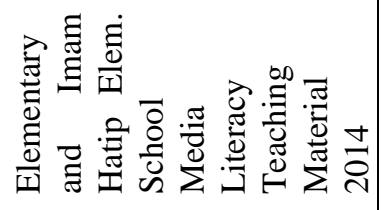 & 93 & 22 & 57 & 15 & 8 & 3 & 7 & 1 & 6 & 25 & 18 \\
\hline
\end{tabular}

Table 1. Media Literacy Lesson Books Content Analysis

When the contents of lesson books that are published in two different periods (2006 and 2014) were examined, it is possible to identify that in media education in Turkey, there is pass to the protective approachment from critical approachment. However, this is especially when we see the sub categories determined in the media literacy lesson which is taught in the scope of media education in Turkey. It is observed in the words "Trust, Protection-Control, hate, ideology, trap, exposure, lie, danger.” Thus, this has passed more frequently in the sentences of the media literacy lesson book which was published in the year 2014. As shown below, there are some sample sentences given from these sub-categories: 
- "You can see many content which include violence and hatred that can be harmful to you in the internet" (Elementary and Imam Hatip Elementary School Media Literacy Teaching Material, 2014)

- "Why media might be producing lie news?" (Elementary and Imam Hatip Elementary School Media Literacy Teaching Material, 2014)

- "Lie or intentional news is continuing to be produced since old ages of the history." (Elementary and Imam Hatip Elementary School Media Literacy Teaching Material, 2014)

- "Media consumption makes it inevitable to fall into the traps of the media” (Elementary and Imam Hatip Elementary School Media Literacy Teaching Material, 2014)

-"An internet world includes dangerous people as much as the good ones..." (Elementary and Imam Hatip Elementary School Media Literacy Teaching Material, 2014). In the year 2006, a softer wording used in the first book belongs to media literacy lesson. We can see criticism about the media tools and the content of the media tools. This was about how they subject children and young people under control in this book. Hence, it includes the sub-category "effect" as its most used sub-category.

-"It is a reality that children in front of the television consistitute the most sensitive and open to effect group" (Primary Media Literacy Class Curriculum and Guide, 2006).

-"The function which constitutes a consumption apetite on the people by the advertisements, films, music, etc. as a commercial tool of the media establishments must be pointed out" (Primary Media Literacy Class Curriculum and Guide, 2006).

\section{Conclusion}

Conclusively, several attempts have been made since 2004 in Turkey about media literacy. As a result of the media, education process has been reorganized under the "start over" slogan in 2014. Suspicious approachment directed to media messages in the course of time has also been observed in two different course materials of media literacy education which is mentioned in this article as well. Furthermore, it has caused us to have a grasp of protective approachment towards even children education in this direction.

In the first source text prepared for the course of Media literacy, children are evaluated as a defenseless receiver in the face of visual, auditory, and printed media. However, it was emphasized that they needed to be put it into a form. Media attention was drawn to the importance of the media literacy in children's discrimination of "fact" and "fiction" in media. In this source "guide book" prepared for teachers in order to remove recite approach for children, unusually, the weight is given to applications for 
children. After this first attempt that can be considered as an important step in the direction of cultivating individuals who can critically look at the media and analyze it (Inal, 2009), the results should be well analyzed. Furthermore, the content prepared for the Children to gain a critical perspective will not be enough by itself.

Before developing a critical attitude towards the media, economic and social factors in the operation of the media and the political system must be recognized. Media, without being seen as a location where the independent messages are, should be considered in the shade of all of these factors. Thus, when educating children and young people to make a critical assessment against the media, these factors must be transferred also. Beyond protecting them from the media, the education activities should be continiued by making them gain skills across different media and having information about the organization and functioning of the media (Asrak Hasdemir, 2009).

Consequently, instead of adopting and implementing only a protective approachment for media content in order to create a structure which is open to democratic dialogue between teacher and student in media literacy education, the process of adopting a participative education concept which is critical and reached the information through experience will show that children and young people act more consciously against media content.

At this point, performing media literacy education for the graduates of communication that have academic information especially about media content in Turkey can be considered as an important step to be taken. Instead of the teachers who have gone through a short education process about media literacy, graduates of communication who have sophisticatedly different information about this issue will be able to explain media content with a more detailed explanation of the causes and consequences of the media.

In digital era, adopting a protective approachment against the media messages which are very numerous will not help in attaining the expected result. Coming face to face with the new media content in internet environment at any moment of the children is now inevitable especially in the digital age we are in. To mention that internet provides facilities and benefits as well as malicious contents in such an environment, makes children to act more consciously against internet without being left behind the new modern trend.

As a result, in this study against changes in time about media literacy course which is constituted in the framework of media education in Turkey, a critical perspective has been endeavored to be presented. Moreover, having a protective perspective against developing technology, diversifying media tools, and enriching media content might cause it to be introverted. On the contrary, by raising generations that has a conscious critical perspective and 
evaluates the media contents in the frameworks, their needs would be a more accurate approachment.

\section{References:}

Alvermann \& Hagood (2010). Critical media literacy: Research, theory, and practice in new times. The Journal of Educational Research (pp. 193-205).

Asrak Hasdemir (2009). Medya okuryazarlığı ve insan hakları: Türkiye örneği. In Gürel Tüzün (Ed.) Ders kitaplarında insan haklarl II, İstanbul: Tarih Vakfi.

Aufderheide (1993). Media literacy: a report of the national leadership conference on media literacy. USA: The Aspen Institute.

Avşar (2014). Medya okuryazarlığı. Iletişim ve diplomasi, 2, Available online at http://goo.gl/0DNluo

Aziz (1990). Araştırma yöntemleri-teknikleri ve iletişim. Ankara: İletişim Araştırmaları Derneği.

Bartlett \& Miller (2011). Truth, lies and the internet a report into young people's digital fluency. London: Demos.

Bazalgatte (2008). Transforming literacy. U. Carlsson, S. Tayie, and G. Jacquinot Delaunay (Ed.), Empowerment through media education: an intercultural dialogue (pp. 245-250). International clearinghouse on children, youth and media, Nordicom: Göteborg University.

Berelson (1952). Content analysis in communication research. New York: Free Press.

Binark \& Gencel Bek (2007). Eleştirel medya okuryazarlı̆̆l. İstanbul:Kalkedon.

Bordac (2014). Introduction to media literacy history. Journal of media literacy education, 6(2), pp.1-2.

Brown (1994). Media literacy perspectives. Journal of communication, 48 (1), pp. 4457.

Buckingham (2009). The future of media literacy in the digital age: some challenges for policy and practice. Medienimpulse, 13-24. Available online at http://goo.gl/H0Z2ON.

Buckingham (1998). Media education in the UK: moving beyond protectionism. Journal of communication, 48 (1), pp. 33-43.

Christ \& Potter (1998). Media literacy, media education, and the academy. Journal of communication, 48(1), pp. 5-15.

Croteau \& Hoynes (2014). Media/society industies, images and audiences. Washington: SAGE

Doğan \& Kılınç (2014). İlkokul düzeyindeki farklı ders kitaplarında barış ve savaş kavramlarına yer veriliş düseyinin karşılaştırmalı olarak incelenmesi. Akademik sosyal araştırmalar dergisi, 2 (1), pp. 277-289. 
Elma et al. (2010). Media literacy education in Turkey: an evaluation of media processes and ethical codes. Educational sciences: theory and practice, 10(3), pp. 1439-1458.

Euroepan Commission (2007). Current trends and approaches to media literacy in europe. Available online at http://goo.gl/RPuXP3.

Fedorov (2008). Media education around the world: brief history. Acta didactica napocensia, 1(2), pp. 56-68.

Fedorov (2003). Media education and media literacy: experts' opinions. Mentor: A media education curriculum for teachers in the mediterranean, 117. Available online at https://goo.gl/mLlS2k.

Gerbner (1958). On content analysis and critical research in mass communication. Educational technology research and development, 6(3), pp.85-108.

Hakansson \& Witmer (2015). Social media and trust - a systematic literature review. Journal of business and economics, 6 (3), pp. 517-524.

Hargrave (2009). Protecting children against harmful content. Directorate general of human rights and legal affairs, Council of Europe.

Hill (2001). Media risks: the social amplification of risk and the media violence debate. Journal of risk research, 4 (3), pp.209-225.

Hobbs (1998). The seven great debates in the media literacy movement. Journal of communication, 48(1), pp. 16-32.

Ilköğretim medya okuryazarlı̆̆ dersi ögretim programı ve kılavuzu (2006). Ankara: Milli Eğitim Bakanlığı, Radyo Televizyon Üst Kurulu.

İnal (2009). Medya okuryazarlı̆̆ el kitabı. Ankara: Ütopya.

Kellner \& Share (2005). Toward critical media literacy: core concepts, debates, organizations and policy. Discourse: studies in the cultural politics of education, 26 (3), pp. 369-386.

Kellner \& Share (2007). Critical media literacy is not an option. Learning inquiry, 1(1), pp. 59-69.

Kellner \& Share (2007). Critical media literacy: crucial policy choices for a twenty-first-century democracy. Policy futures in education, 5 (1), pp. 59-69. Krippendorf (2004). Reliability in content analysis some common misconceptions and recommendations. Human communication research, 30 (3), pp. 411-433.

Livingstone (2004). What is media literacy? Intermedia, 32 (3), pp. 18-20.

Livingstone (2004). Media literacy and the challenge of new information and communication technologies. The communication review, 7 (1), pp. 3-14.

Mar, Tackett, \& Moore (2009). Exposure to media and theory-of-mind development in preschoolers. Cognitive development.

McQuail (1977). The influence and effects of mass media. In J. Curran, M. Gurevitch and J. Woolacott (Ed..) Mass communication and society, (pp.7094). Sage Publications. 
Media Awareness Network (2012). Responding to online hate. Canada: Media Awareness Network

Nacaroğlu (2006). Etkin bir medya okuryazarlığı için yerel olanak ya da olanaksızlıklar. In N.Türkoğlu (Ed.) Medya okuryazarlı̆̆ (pp.81-87). İstanbul:Marmara Üniversitesi İletişim Fakültesi

Napoli (2014). Measuring media impact an overview of the field. The Lear Center.

Orhon, N.E., Pembecioğlu, N., Altun, A.,Tüzel, S. and Çakmak, E. (2014). Ortaokul ve imam hatip ortaokulu medya okuryazarlı̆̆ öğretim materyali. Ankara: Milli Eğitim Bakanlığı Yayınları.

Potter (2004). Theory of media literacy a cognitive approach. USA: Sage Publications.

Prasad (2008). Content analysis, a method in social science research. In Lal Das, D.K and Bhaskaran, V (Ed.) Research methods for social work (pp. 173-193). New Delhi: Rawat.

Querol (2016). Zygmunt Bauman: social media are a trap. El Pais. Available online at http://goo.gl/4QLX4r

Radyo Televizyon Üst Kurulu (RTÜK) (2007). İlköğretim medya okuryazarlı̆̆ı dersi öğretmen el kitabı. Ankara: RTÜK.

Radyo Televizyon Üst Kurulu (RTÜK) (2007). Medya okuryazarlı̆̆ hakkında yayınlar. Available online at http://goo.gl/c6b6Le

Roberts \& Foehr (2008). Trends in media use. The future of children, 18 (1), pp.1-37.

Semali (2003). Ways with visual languages: Making the case for critical media literacy. The clearing house: A journal of educational strategies, Issues and Ideas, 76 (6), pp. 271-277.

Stemler (2001). An overview of content analysis. practical assessment, Research and evaluation, 7(17). Available online at http://goo.gl/iu9fT

Thierer (2009). Parental controls and online child protection: a survey of tools and methods. The progress \& freedom foundation, Available online at http://goo.gl/ijCACd

Tufte (2003). Children, media and consumption, young consumers. International journal of advertising and marketing to children, 5 (1), pp. 6976.

Türkiye Büyük Millet Meclisi (2004). Şiddeti önleme platformu medya ve şiddet çalışma grubu raporu. Available online at http://goo.gl/hgE3Ly

Thoman \& Jolls (2008). 21. yüzyıl okuryazarlığı: medya okuryazarlı̆̆ına genel bir bakış ve sınıf içi etkinlikler. C. Elma and A. Kesten, (Trans.) Ankara: Ekinoks Yayınevi.

Whitaker \& Bushman (2009). Online dangers: keeping children and adolescents safe. Wash. and Lee L. Rev, 66, pp.1053- 1063. 
Yıldırım \& Şimşek (2006). Sosyal bilimlerde nitel araştırma yöntemleri. Ankara: Seçkin. 